\title{
Macroinvertebrates Inhabiting the Tank Leaf Terrestrial and Epiphyte Bromeliads at Reserva Adolpho Ducke, Manaus, Amazonas
}

\author{
Sharlene Roberta da Silva Torreias* and Ruth Leila Ferreira-Keppler \\ Coordenação de Biodiversidadel INPA; C. P.: 478; 69011-970; Manaus - AM - Brasil
}

\begin{abstract}
The aim of this work was to investigate the diversity of macroinvertebrates and also verify if the abundance and diversity of Diptera were influenced by the abiotic factors. The samples were collected from the epiphytic and terrestrial bromeliads $G$. brasiliensis (1 and $3 m$ ) in wet and dry seasons at Reserva Adolpho Ducke analyzed total of 144 samples were analyzed from a total of 15,238 individuals collected. These conatined 14,097 insects and, among these, 8,258 were immature Diptera, represented by eight most abundant families: Chironomidae, Ceratopogonidae and Culicidae. The relationship of Diptera diversity was influenced by the seasons and stratifications $(p=0.01)$; the abundance was influenced by the volume of water $(p=0.02)$ and the relationship between the season and volume of water in the terrestrial bromeliads was significant $(p=0.01)$. This study represented the first contribution to knowledge of community of macroinvertebrates associated to bromeliads G. brasiliensis in Central Amazon.
\end{abstract}

Key words: Amazon, Bromeliaceae, Guzmania, Macroinvertebrates, Phytotelm

\section{INTRODUCTION}

Natural habitats from the plants that accumulate the rain water (phytotelmata) (Varga, 1928) are ideal breeding sites for several macroinvertebrates, whose size is bigger than $1 \mathrm{~mm}$, visible by naked eye, and could be retained in the nets ranging from 0.2 to $0.5 \mathrm{~mm}$ mesh size. (McCafertty, 1983). Such habitats offer favorable conditions for colonizing and development of the individuals from different species which are distributed among many water invertebrate families (Fish, 1983; Kitching, 2000, 2001). Bromeliads hold water reservoirs throughout the year, maintaining the complex food chains, such as bacteria, algae and a variety of invertebrates such as crustaceans, arachnids, nematodes, oligochaetes and insects, including the abundant and diverse Diptera (Fish, 1983; Frank, 1983). The Diptera order is divided in two suborders: Nematocera and Brachycera (Forattini, 2002), having 125 families and 130,000 species that inhabit the artificial breeding (e.g. tires, cans, tins, vases) and non-artificial breeding areas (ponds, lakes, puddles, etc) such as phytotelmata (bromeliads, tree holes, plants axils) where immature forms are semi-water and water-adapted (Kitching, 2000; Greeney, 2004). In order to maintain these numerous communities of arthropods, the importance of these organisms as well as the ongoing processes occurring in these habitats have been widely discussed in phytotelmata ambiances (Erwin, 1982). In these

*Author for correspondence: rtorreias@gmail.com 
environments, abundance is mainly regulated by the availability of resources like the organic detritus and physicochemical water conditions, such as the volume, $\mathrm{pH}$, temperature and electrical conductivity. Other characteristics such as size, height (different stratifications) of the phytotelmata and season periods, directly affect both the water and organic matter quantity and quality that eventually impact the associated communities (Richardson, 1999; Kitching, 2001).

Thus, the associated fauna is specific to these environments, represented mostly by the insects, with 70 families and 11 orders recorded so far, with Diptera as the most abundant and common (Greeney, 2001). The immature forms find ideal conditions to reproduce and colonize, completing at least one development stage in the water stored in these microhabitats (Frank, 1983), having an important role structuring the associated community, acting as decomposers and filteringcollectors of organic matter in water and/or preying other organisms, thus establishing several ecological interactions (Richardson, 1999; Kitching, 2000). The purpose of this work was to study the macroinvertebrates in Guzmania brasiliensis with emphasis on Diptera, and to explain the relationship of these insects with the environment. Thus, the objectives were to: i) identify the associated fauna of macroinvertebrates; ii) verify the stratification influence (epiphytic and terrestrial) and season periods (rainy and dry) on the abundance and diversity of Diptera populations; iii) evaluate if the abundance and diversity of Diptera were influenced by the volume of water and iv) evaluate if the volume of the water retained in the bromeliads was influenced by the seasonal periods.

\section{MATERIAL AND METHODS}

The study was conducted at the Reserva Florestal Adolpho Ducke (02 $55^{\prime}$ S59 $\left.59^{\circ} \mathrm{W}\right)$, Manaus, Amazonas, in an area of "campinarana" forest, which was characterized for its compound soil of white sand and litter, partially closed canopy and trees with 15 to $25 \mathrm{~m}$ height (Ribeiro et al., 1999). Twelve samplings were done between April 2003 and April 2005: six in the rainy season (April, May and June, 2003; March 2004; March and April 2005) and six in the dry season (August,
September and October 2003; August, September and October 2004). In each sampling month, 12 bromeliads of $G$. brasiliensis, six terrestrial and six epiphytic (height between 1 and $3 \mathrm{~m}$ ), were collected, making a total of 144 samples. The physicochemical variables of the water, such as $\mathrm{pH}$, electrical conductivity $(\mu \mathrm{S} / \mathrm{cm})$, temperature $\left({ }^{\circ} \mathrm{C}\right)$ and volume $(\mathrm{mL})$ were measured in all the bromeliads. To characterize and confirm the two seasonal periods, data on the rainfall levels $(\mathrm{mm})$ and temperature $\left({ }^{\circ} \mathrm{C}\right)$ were collected at Estação Experimental EMBRAPA/ Amazônia Ocidental, at AM 010 inter-road, Km 30. At the laboratory, the samples were screened and individuals were alcohol-fixed (alcohol 80\%) for identification at family level by using the McCafferty (1983) and Merritt and Cummins (1996a) taxonomic keys. The adopted nomenclature was based on Triplehorn and Johnson (2005). In order to functionally categorize the macroinvertebrates, the Merritt and Cummins (1996a) and Kitching (2000) bibliography were utilized. All the collected material was stored at the Coleção de Invertebrados do Instituto Nacional de Pesquisas da Amazônia - INPA as an ecological proof as well as reference for future taxonomic and systematic studies related to macroinvertebrates associated to Bromeliaceae.

\section{Statistical Analysis}

To check the seasonal influence (dry and rainy periods) and stratification (epiphyte and terrestrial) on Diptera's diversity and abundance, Manova (Factorial ANOVA) was used. The Tukey's test was a posteriori test to check which variables were significant. To check the diversity of the Diptera and abundance on the volume of water, simple regressions were done. The $t$-test was used to check if the amount of water contained in both epiphyte and terrestrial bromeliads was influenced by the seasonal periods (dry and rainy). In all the statistical analysis, the applied significance was $\mathrm{p}<$ 0.05 (Zar, 1996). The abundance of each family on both the stratifications was calculated by the sum of the individuals and the occurrence frequency divided by the percentage of bromeliads families out of the total number of samples. The analyses were done only with Diptera order, since they were very frequent organisms and important members in structuring the associated community (Sota, 1998, Paradise, 2004). 


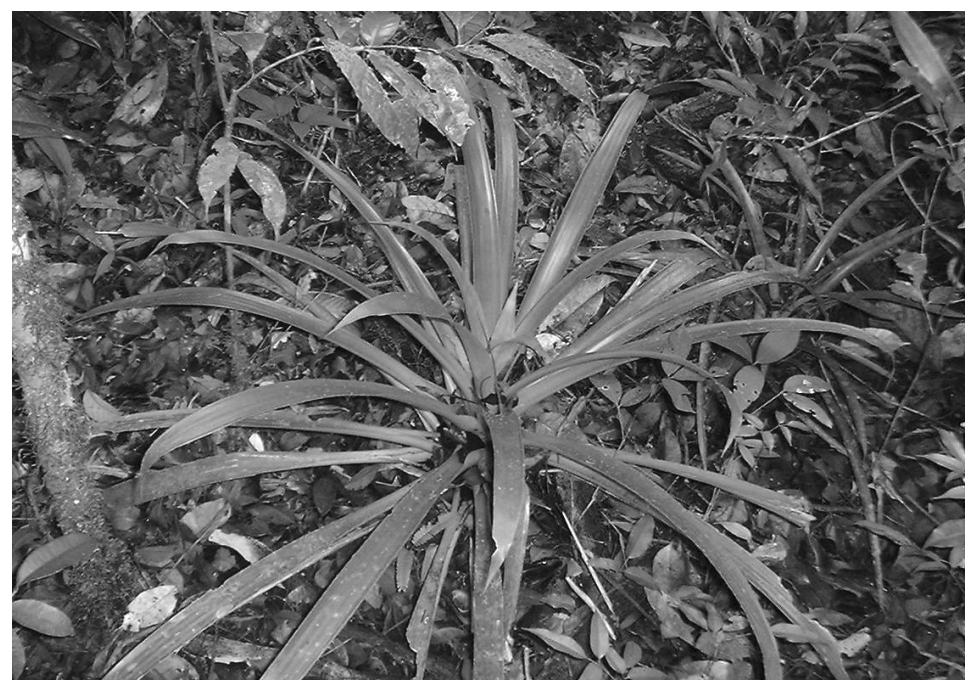

Figure 1 - General view on G. brasiliensis terrestrial bromeliads at "campinarana" forest at Reserva Ducke, Manaus, Brazil.

\section{RESULTS AND DISCUSSION}

From 144 bromeliads analyzed, 15,238 macroinvertebrates individuals were collected, which were distributed among the Malacostraca, Arachnida, Chilopoda, Diplopoda, Oligochaeta and Insecta classes, with Insecta being the most abundant, with 14,097 individuals, distributed on the following taxa: Diptera, Coleoptera, Hymenoptera, Hemiptera, Lepidoptera, Odonata, Dermaptera, Blattodea and Isoptera, representing twenty-three families (Table 1). Such complex system was formed by various groups of macroinvertebrates, as reported earlier also (Mestre et al., 2001; Frank et al., 2004; Liria, 2007) for example terrestrial and epiphytic Vriesea Lindley, 1843, Tillandsia L. 1753 Aechmea Ruiz and Pavón, 1974 respectively. Phytotelmata, as the bromeliads, containing aloctonous food resources, and debris based on associated communities, might have trophic levels divided in saprophages, predators and top predators, which varied depending on the number of species, particles, debris they explored and for the predators it depended on the behavior strategies (Kitching, 2000). The number of the Diptera was composed by 8,258 , confirming the high occurrence in Vriesea, Tillandsia, Aechmea and Hohenbergia Shult.f., 1830 bromeliads (Mestre et al., 2001; Liria, 2007). Other studies have shown the evidences of a well-succeeded colonization from this order in other phytotelmata. The Diptera group is the most important group of aquatic insects in terms of representativeness and diversity (Kitching, 2001; Greeney, 2004) thus becoming important members in these environment's chain food (Richardson, 1999; Kitching, 2000) for serving as food for predators (e.g. Coleoptera and Odonata), or for establishing other ecological connections in view of the variation of the functional categories of the cited families (Laessle, 1961; Kitching, 2001).

In the Diptera order, the Chironomidae family was the highest frequency level of occurrence in the stratifications (terrestrial and epiphyte) and in the two seasonal periods studied (Table 2) as well as the highest representativeness having $28.43 \%$ out of the total number of individuals collected throughout the collecting moths (Table 1). Reiss (1977) reported that this family was an important element in the aquatic food chain because it colonized many high-density habitats such as puddles, ponds and phytotelmata. In addition to that, the feeding plasticity and ecological amplitude, favored by the morphological, physiological and behavioral adaptations, gave conditions for succeeding in various aquatic ecosystems under different environmental conditions (Coffman and Ferrington, 1996). 
Table 1 - Absolute and relative abundance of macroinvertebrates collected in G. brasiliensis from April/2003 to April 2005, at Reserva Ducke, Manaus, AM.

\begin{tabular}{|c|c|c|c|c|c|}
\hline Phylum & Subphylum & Class & Order & Family/Functional Category & Abundance \\
\hline \multirow[t]{8}{*}{ Arthropoda } & Atelocerata & Insecta & Diptera & Chironomidae (predator/collector-filter) & $4319(28.43 \%)$ \\
\hline & & & & Ceratopogonidae (decomposer/filter) & $1093(7.17 \%)$ \\
\hline & & & & Culicidae (collector-filter) & $842(5.53 \%)$ \\
\hline & & & & Tabanidae (predator) & $815(5.35 \%)$ \\
\hline & & & & Tipulidae (predator) & $753(4.94 \%)$ \\
\hline & & & & Psychodidae (decomposer) & $154(1.01 \%)$ \\
\hline & & & & Corethreliidae (predator) & $152(1 \%)$ \\
\hline & & & & Syrphidae (collector/decomposer) & $130(0.85 \%)$ \\
\hline \multirow{16}{*}{\multicolumn{2}{|c|}{ Sub-total Diptera }} & & & & 8,258 \\
\hline & & & Coleoptera & Scirtidae (collector-filter) & $3425(22.28 \%)$ \\
\hline & & & & Carabidae (predator) & $143(0.94 \%)$ \\
\hline & & & & Dytiscidae (predator) & $95(0.62 \%)$ \\
\hline & & & & Staphylinidae (predator) & $42(028 \%)$ \\
\hline & & & & Noteridae (predador) & $55(0.36 \%)$ \\
\hline & & & & Elmidae (scraper) & $4(0.03 \%)$ \\
\hline & & & & Gyrinidae (predator) & $2(0.01 \%)$ \\
\hline & & & & Discolomidae (undetermined) & $1(0.01 \%)$ \\
\hline & & & Hymenoptera & Formicidae (om nivore) & $1725(11.32 \%)$ \\
\hline & & & Hemiptera & Veliidae (predator) & $124(0.81 \%)$ \\
\hline & & & Lepidoptera & Pyralidae (fragmenting) & $81(0.53 \%)$ \\
\hline & & & Odonata & Conagrionidae (predator) & 50. $(0.33 \%)$ \\
\hline & & & Dermaptera & Forficulidae (predator) & $47(0.31 \%)$ \\
\hline & & & Blattodea & Blattidae (detritivore) & $32(0.21 \%)$ \\
\hline & & & Isoptera & Termitidae (decomposer) & $13(0.09 \%)$ \\
\hline \multicolumn{2}{|c|}{ Sub-total Insecta } & & & & 14,097 \\
\hline & Crustacea & Malacostraca & Isopoda & undetermined/decomposer & $388(2.55 \%)$ \\
\hline & Chelicerata & Arachnida & Araneae & undetermined/predator & $305(2 \%)$ \\
\hline & & Chilopoda & & undetermined/predator & $30(0.2 \%)$ \\
\hline & & Diplopoda & & undetermined/herbivore & $52(0.34 \%)$ \\
\hline Annelida & & Oligochaeta & & undetermined/decomposer & $366(2.4 \%)$ \\
\hline
\end{tabular}

According to Kitching (2000), Chironomidae codominate the entomofauna in phytotelmata, being the most important component in terms of living biomass. While studying the gender Aechmea and Hohenbergia in Venezuela, Liria (2007) also found a higher abundance and diversity in the Chironomidae family, which were $43 \%$ out of the total of individuals. The Ceratopogonidae had a low relative abundance $(7.17 \%)$; nevertheless, they were found in more than half the samples analyzed $(52 \%)$, revealing that this group was frequent at the studied phytotelmata. Similarly, the immature forms of Ceratopogonidae were commonly found in the tree holes, bamboo internodes, and bananabrava trees' overlapping leafs (Strelitziaceae), where often the insect fauna dominated, represented by the genera Culicoides Meigen, 1818 and Forcipomyia Meigen, 1818 (Kitching, 2000). The Culicidae had $5.53 \%$ of relative abundance and a high frequency occurrence in $88 \%$ of the studied bromeliads (Table 2). This family $o p$ cit was quite common in the phytotelmata directly revealing an intimate association with these types of environment (Forattini, 2002), probably enhanced by the morphological, feeding and reproductive adaptations (collectors and filter feeders of the organic matter) (Richardson and Hull, 2000; Frank et al., 2004; Ospina-Bautista et al., 2004). In Central Amazon, there were some records about the Guzmania Ruiz and Pavón, 1802 at Reserva Florestal Adolpho Ducke (Torreias et al., 2010) for two Culicidae genera. Wyeomyia Theobald, 1901, can develop its individuals at the breedings sites formed in araceae, musaceae, bamboos, tree holes, fallen leaves (Kitching, 2000; Torreias, 2008) and Culex (Microculex) Theobald, 1901 which are specialized in making use of natural water 
breeding sites, mainly represented by the bromeliads (Marcondes, 2001). Other dipterous were found with less abundance: Tabanidae (5.35\%), Tipulidae (4.9\%), Corethreliidae (1\%), Psychodidae $(1 \%)$ and Syrphidae $(0.85 \%)$ (Table I). The Corethrellidae larvae are aquatic or semiaquatic and can develop in the phytotelmata, especially bromeliads. However, there is very little information about this group, mainly for the species found in the Amazon rain forest (Papavero, 2002). As for the functional aspect, they are predators and if necessary cannibal (personal observation Torreias, 2008). The immature Psychodidae take shelter under the humid and plenty of organic matter around or inside the aquatic ambiances. Under these conditions, they are regular inhabitants specialized in colonizing the phytotelmata (Thienemam, 1934) such as tree holes, bromeliads, bamboos and Heliconia caribaea Lam. 1785 inflorescences (Salamandra, 1980; Mestre et al., 2001). The Tipulidae larvae are found in both the aquatic and terrestrial ambiances, being very common on the sediment, epiphyte bromeliad leaves, rotten pieces of logs, brunches and leaves (Kitching, 2000). Louton et al. (1996) found Psychodidae, Tipulidae and Syrphidae immatures in bamboos (Poaceae) internodes in Peruvian forests. The size of the hole in the bamboo internodes directly affected the succession of the associated fauna (especially Diptera), consequently raising the abundance of the individuals and the diversity of the species, where the females actively participated in the recolonization through oviposition, including the dry periods. The Syrphidae showed a diversification of niches, making them good environmental markers. Many of them are aphid predators, in social insects' nests, plants or rotten wood. There were immature forms of Chrysogasterini and Eristalini tribes and the Quichuana Knab, 1913, identified in the bamboos in Amazon rain forest (Louton et al., 1996). The Tabanidae were found from the rotten and/or humid pieces of the wood in the accumulated water in the phytotelmata (e.g. Bromeliaceae, Araceae and Arecaceae) (McCafferty, 1981; Marcondes, 2001. In the bromeliads, there was the presence of the Stibasoma Schiner, 1867 and Fidena Walker, 1850. These two genders found a diversified food resource by predating the dipteran larvae, absorbing the body fluids from them (Greeney, 2001; Torreias, 2008). Due to the high abundance in the samples, data from other groups of the insects collected are shown in Table 1. The Coleoptera was represented by eight families, revealing that they were very frequent and abundant in the bromeliads as also found by Kitching (2000). The Scirtidae are supposedly leaf-surface shredders/scrapers. By scraping or shredding these leaves, they raise the level of fragmented organic matter in these ambiances. In the bamboo internodes and tree holes filter species are found (Kitching, 2000). Other families of the aquatic Coleoptera such as Carabidae, Dytiscidae, Gyrinidae and Noteridae have always been reported due to the availability of the preys in the bromeliad biota. As wide predators, they feed on many organisms. However, according to (Kitching, 2000) they prefer Culicidae, Chironomidae, Ceratopogonidae tadpoles and earthworms larvae, causing a possible and considerable reduction in the density of these organisms. As for terrestrial beetles (Staphylinidae), they also have this predator habit, feeding on mosquito larvae (Wyeomyia) next to the water surface (Kitching, 2000; Greeney, 2004). According to Kitching (2000), the Heteroptera are represented in the phytotelma by the Gerridae, Hydrometridae and Vellidae families. Differently, in the Central Amazon, the bromeliads are represented by the Paravelia Breddin, 1898 and Microvelia Westwood, 1834 (Vellidae) Heteroptera constantly found genera, feeding on other aquatic immature insects, mosquito larvae and annelids. Therefore, despite occupying the pleuston, the Veliidae are moderated predators that may alter the availability of the prey for other predators, influencing the occupation dynamic, affecting the preys' diversity and abundance. Pereira et al. (2007) demonstrated the occurrence of Paravelia recens Drake and Harris, 1935 in the terrestrial and tree bromeliads of $G$. brasiliensis at Reserva Florestal Adolpho Ducke. The Annelida, another very important group in the bromeliad tanks, act like "macrosaprophages"by tearing the thick organic matter into tiny particles, resulting in benefitting the groups that feed on these small particles and debris suspended on the water (e.g. collectors-filters: Culicidae and microcrustaceans decompositers: Isopoda) (Kitching, 2001). Moreover, there are some organisms that do not belong to the bromeliads' specific fauna that make use of it as feeding areas (e.g. Formicidae) (Oliveira, 1995). Also, capturing the insects under the dry leaves adults ermerge, e.g. Arachnida, 
Chilopoda and Staphylinidae (Ospina-Bautista et al., 2004; Sanchez and Liria, 2009).

\section{The Influence of Physicochemical variables on the Dipterofana's Water}

Out of the 8,259 immature, 3,312 occurred during the rainy period and 4,947 during the dry period (Table 2). The dry season period showed the highest level of abundance in August/04, with 1,215 individuals (Fig. 2) and the "epiphyte" stratum the most representative with 4,766 individuals. The "terrestrial" stratum had 3,492 individuals. The water volume on the bromeliads varied between 50 and $450 \mathrm{~mL}$, the $\mathrm{pH} 4.6$ to 6.9 , the electrical conductivity between 10 to $50 \mu \mathrm{S} / \mathrm{cm}$ and the temperature was about $27^{\circ} \mathrm{C}$. The weather data revealed a higher temperature in October/03 and November/04, higher raining rates in March/04 and April/05, surpassing 400mm of rain level, expected results for the area in the two different seasonal periods (Fig. 2).

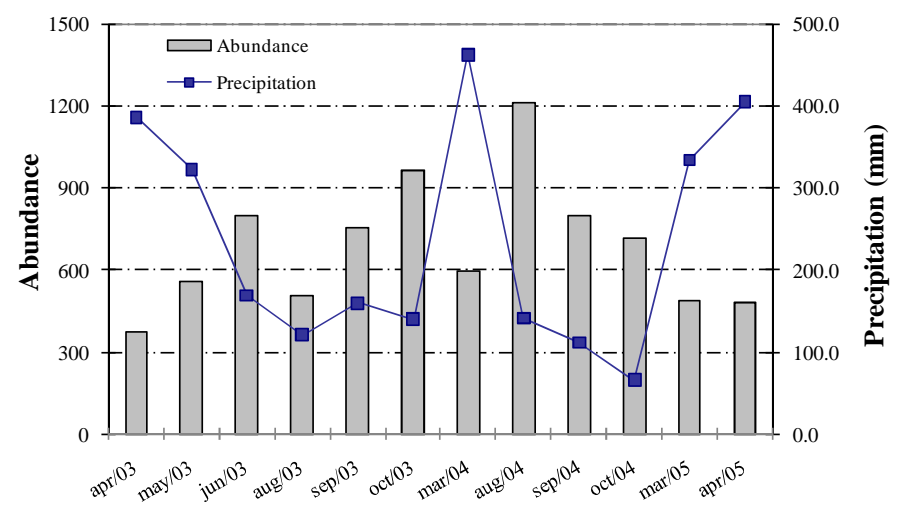

Figure 2 - Diptera immatures on G. brasiliensis axils at Reserva Ducke, Manaus, AM. Abundance in relation to precipitation ( $\mathrm{mm}$ ), between April/03 and April/05.

Table 2 - Abundance and occurrence frequency (OF) on Diptera families collected on dry and rainy periods and terrestrial and epiphyte stratifications of G. brasiliensis between April/03 and April/05 at Reserva Ducke, Manaus, AM.

\begin{tabular}{|c|c|c|c|c|c|c|c|c|}
\hline \multirow[b]{2}{*}{ Family } & \multicolumn{2}{|c|}{ Epiphyte/Rainy } & \multicolumn{2}{|c|}{ Terrestrial/Rainy } & \multicolumn{2}{|c|}{ Epiphyte/Dry } & \multicolumn{2}{|c|}{ Terrestrial/Dry } \\
\hline & Abundance & OF & Abundance & OF & Abundance & OF & Abundance & OF \\
\hline Ceratopogonidae & 285 & 80.56 & 216 & 69.44 & 287 & 83.33 & 305 & 52.78 \\
\hline Chironomidae & 849 & 91.67 & 875 & 91.67 & 1717 & 94.44 & 878 & 88.89 \\
\hline Corethreliidae & 41 & 47.22 & 26 & 38.89 & 31 & 38.89 & 54 & 52.78 \\
\hline Culicidae & 141 & 83.33 & 116 & 77.78 & 430 & 88.89 & 155 & 69.44 \\
\hline Psychodidae & 62 & 36.11 & 28 & 13.89 & 34 & 27.78 & 30 & 38.89 \\
\hline Syrphidae & 13 & 19.44 & 43 & 27.78 & 40 & 38.89 & 34 & 52.78 \\
\hline Tabanidae & 188 & 80.56 & 138 & 75.00 & 265 & 94.44 & 224 & 94.44 \\
\hline Tipulidae & 139 & 69.44 & 151 & 72.22 & 244 & 88.89 & 219 & 91.67 \\
\hline \multirow[t]{2}{*}{ Sub-total } & \multirow[t]{2}{*}{1,719} & & \multicolumn{2}{|c|}{1,593} & \multicolumn{2}{|c|}{3,048} & \multicolumn{2}{|c|}{1,899} \\
\hline & & \multicolumn{3}{|c|}{ Rainy $=3,312$} & \multicolumn{4}{|c|}{ Dry $=4,947$} \\
\hline
\end{tabular}

The Manova (Factorial Anova) showed significance for the diversity in relation to the two periods and stratifications studied $(\mathrm{p}=0.01)$. The dry period was the most influent on the test (Fig. 3 ), differing from the abundance of individuals, where the test was not significant $(\mathrm{p}=0.38)$. The simple regressions to check the volume of water $(\mathrm{mL})$ in the bromeliads over the abundance and diversity of dipterans were significant only for the abundance of individuals $(\mathrm{p}=0.02)$ (Fig. 4). The $t$-test to check the influence of the seasonal periods (dry and rainy) over the volume of water $(\mathrm{mL})$ in 
the terrestrial and epiphyte bromeliads was significant only for the terrestrial stratification $(\mathrm{p}<$ 0.01) (Fig. 5). Liria (2007) compared the bromeliad fauna in the rainy and dry periods and obtained a significant increase in the specimen diversity as well as an increase in the diversity of the Culicidae in the dry period. According to Greeney (2001) throughout the rainy period, the entomofauna was more spread due to the higher quantity of the plants containing water. Conversely, throughout the dry period, the opposite process took place: a lower quantity of water available in the phytotelmata, causing the gathering of bromeliads colonizing species on other water-container plants. This resulted a significant increase in the abundance of the specimen and diversity in the plants that contained water during the dry period. In phytotelmata, the associated community must be adapted to the dynamics that occur in these living ambiances caused by the successive evaporation, decomposition and substitution processes due to the ephemeral effect of the water influenced by the different seasonal periods (Kitching 2000). During the long lasting dry periods, when the physicochemical conditions and the quantity of water and nutrients are scarce, the few reservoirs that can retain water are responsible by maintaining the population, being able to keep the biota dynamics and entomofauna balance until the rainy season.

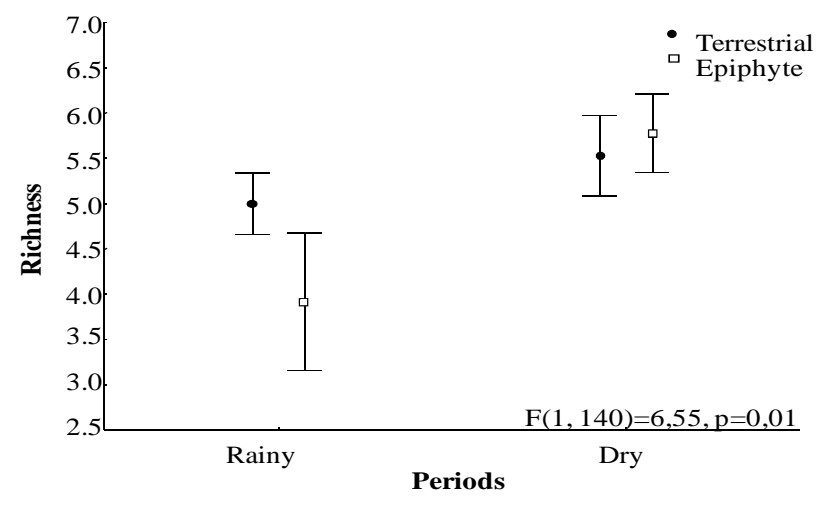

Figure 3 - Manova between the Diptera families collected in rainy and dry periods and terrestrial and epiphyte stratifications $(\mathrm{p}=0.01 ; \mathrm{n}=144)$ between April/03 e April/05 at Reserva Ducke, Manaus, AM.

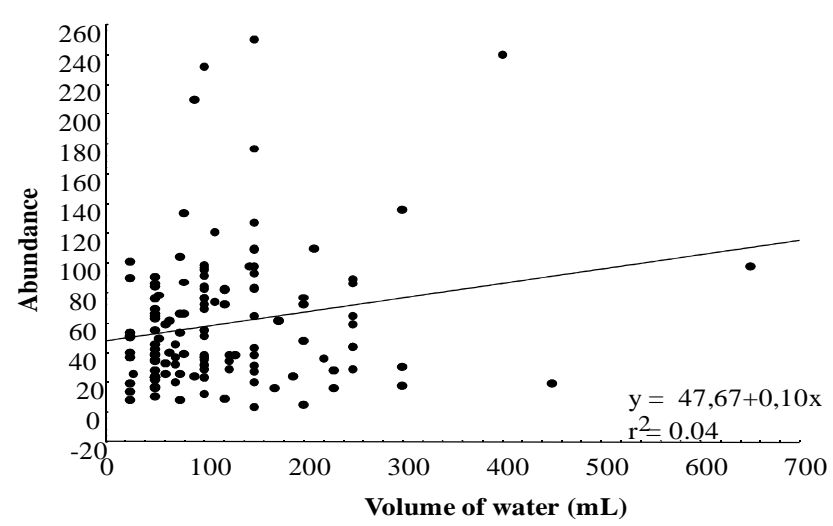

Figure 4 - Simple regression between Diptera immature and volume of water $(\mathrm{mL})(\mathrm{p}=0.02)$ in epiphyte and terrestrial bromeliads $(\mathrm{n}=144)$ of $G$. brasiliensis, collected between April/03 and April/05 at Reserva Ducke, Manaus, AM. 


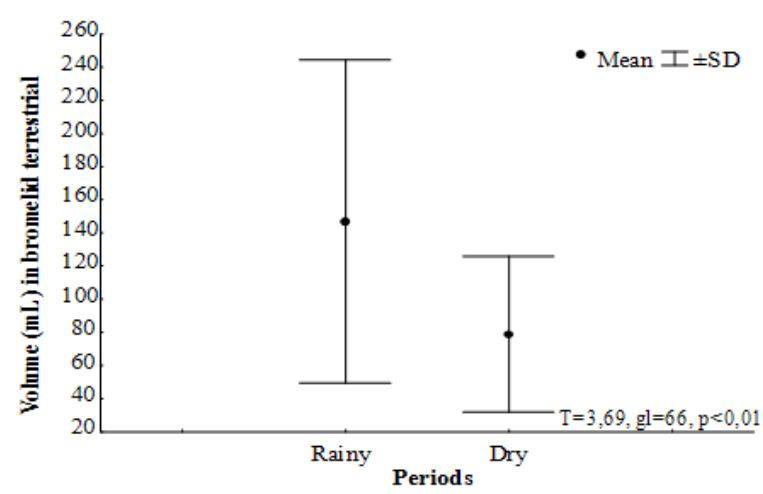

Figure 5 - Comparison between the seasonal periods (dry and rainy) and volume of water $(\mathrm{mL})$ by using the "T" test in G. brasiliensis terrestrial bromeliads between April/03 and April/05 at Reserva Ducke, Manaus, AM.

In relation to the stratifications, Mestre et al. (2001) noticed that there were no statistical difference between the entomofauna studied and stratifications (terrestrial and epiphyte bromeliads) of Vriesea splendens Lem., 1850. These authors, however, checked the individuals significant abundance found in the epiphyte bromeliads throughout different seasons in the South region in Brazil (Paraná), matching with the present study. The water from the precipitation and the aloctonous food resource, contained in the plants structures (e.g. over-lapping and tank leaves) (Frank and Lounibos, 1983) become the food base for the aquatic organisms plus the mating rituals and egg-laying processes (Kitching, 2000), consequently helping the dipterans abundance and diversity dominancy. Benzing (1980), Fish (1983), Frank et al. (2004) found that the volume of water was one of the main abiotic factors that influenced the phytotelmatas' entomofauna. Ospina-Bautista et al. (2004) found a positive correlation between the individuals diversity and abundance and the volume of water held in Tillandsia (Bromeliaceae). In Central Amazon this study represented the first record of the invertebrates in G. brasiliensis axils, revealing that this bromeliad phytotelmata had a high diversity of the families, where the Insecta Class was dominant. These results contributed to the importance of maintaining such landscape element as well as the macroinvertebrates in their natural habitat, bringing balance in the natural systems, contributing to the knowledge of Amazon biodiversity.

\section{ACKNOWLEDGMENTS}

Thanks to CNPq n ${ }^{\circ} 480105 / 2007-3$, PRJ.PPI 12.13 (Biologia, Ecologia e Sistemática de Insetos na Amazônia) and INPA for the financial and logistical support. To researcher Maria de Lourdes Morais from Coordenação de Biodiversidade/ INPA for the bromeliad identification. To the technician Jaílson Vidal for the filed collection and Janny Fernandes for helping screening the material. To Wilson Freire who translated the manuscript.

\section{REFERENCES}

Benzing, D.H. (1980), The biology of the bromeliads. Mad River Press, Eureka, Califórnia. 304p.

Coffman, W.P.; Ferrigton, Jr. L.C. 1996. Chironomidae, pp. 635-754. In: Merritt, R.W.; Cummins, K.W. (eds.). An Introduction to the aquatic insects of North America. Kendall/Hunt Publishing Company. USA.

Erwin, T.L. (1982), Tropical forests: their richness. In: Coleoptera and other arthropod species. Coleopt. Bull., 36, 74-75. 
Fish, D. (1983), Phytotelmata: Flora e Fauna, p. 1-28. In: Frank, J.H. and Lounibos, L.P. (Eds.). Phytotelmata: Terrestrial Plants as Host for Aquatic Insect Communities. Plexus, Medford, New Jersey.

Frank, J.H. (1983), Bromeliad phytotelmata and their biota, especially mosquitoes. p. 101-128. In: Frank, J.H. and Lounibos, L.P. (Eds). Phytotelmata: Terrestrial Plants as Host for Aquatic Insect Communities. Plexus, Medford, New Jersey. 243pp.

Frank, J.H.; Lounibos, L.P. (1983), Phytotelmata: Terrestrial Plants as Host for Aquatic Insect Communities. Plexus, Medford, New Jersey. 293pp.

Frank, J.H.; Sreenivasan, S.; Benshoff, P.J.; Deyrup, M.A.; Edwards, G.B.; Halbert, S.E.; Hamon, A.B.; Lowman, E.L.; Mockford, E.L.; Scheffrahn, R.H.; Steck, G.J.; Thomas, M.C.; Walker, T.J. and Welbourn, W.C. (2004), Invertebrate animals extracted from native Tillandsia (Bromeliales: Bromeliaceae) in Sarasota County, Florida. Fla. Entomol., 87(2), 176-185.

Forattini, O.P. (2002), Culicidologia Médica. Vol.2: Identificação, Biologia, Epidemiologia. Editora Universidade de São Paulo. 860pp.

Greeney, H.F. (2001), The insects of plant-held waters: a review and bibliography. J. Trop. Ecol., 17, 241260.

Greeney, H.F. (2004), Fallen flower bracts of the stiltroot palm Iriartea deltoidea (Palmae: Iriarteeae) as phytotelmata habitats in a lowland Ecuadorian rainforest. Contrib. Biol. Geol., 101, 1-20.

Kitching, R.L. (2000), Food webs and container habitats: the natural history and ecology of phytotelmata. Cambridge Univ. Press, Cambridge, USA, 431pp.

Kitching, R.L. (2001), Food webs in phytotelmata: "bottom-up" and "top-down" explanations for community structure. Annu. Rev. Entomol., 46, 729760.

Laessle, A.M. (1961), A micro-limnological study of Jamaican bromeliads. Ecology, 42, 499-517.

Liria, J. (2007), Fauna fitotelmata em las bromélias Aechmea fendleri André y Hohenbergia stellata Schult del Parque Nacional San Esteban, Venezuela. Rev. Peru. Biol., 14(1), 33-38.

Louton, J.; Gelhaus, J. and Bouchard, R. (1996), The Aquatic Macrofauna of Water-Filled in Bamboo (Poaceae: Bambusoideae: Guadua) Internodes in a Peruvian Lowland Tropical Forest. Biotropica, 28(2), 228-248.

Marcondes, C.B. (2001), Entomologia Médica Veterinária. Editora Atheneu, São Paulo. 432pp.

McCafferty, W.P. (1983), Aquatic Entomology. The fishermen's and Ecologists-Illustrated Guide to Insects and Their Relatives. Jones and Bartlett Publishers, London. 448pp.
Merritt, R.W.; Cummins, K.W. (1996a), An introduction to the Aquatic Insects of North America. Dubuque: Kendall/Hunt Publishing. 862pp.

Mestre, L.A.M.; Aranha, J.M.R. and Esper, M.L.P. (2001), Macroinvertebrate fauna associated to the bromeliad Vriesea inflate of the Atlantic Forest (Paraná State, Soulther, Brazil). Braz. Arch. Biol. Techn., 44(1), 89-94.

Oliveira, M.G.N.; Rocha, C.F.D. and Bagnall, T. (1995), A comunidade animal associada à broméliatanque Neoregelia cruenta (R. Graham) L.B.Smith. Rev. da Soc. Bras. de Bromélias, 1: 22-29.

Ospina-Bautista, F.; Estevez-Varon, J.V.; Betancur, J. and Realpe-Rebolledo, E. (2004), Estructura y composición de la comunidad de macro invertebrados acuáticos asociados a Tillandsia turneri Baker (Bromeliaceae) en un bosque alto andino colombiano. Acta Zool. Mex., 20(1), 153-166.

Papavero, N. (2002), Insecta-Diptera-Chaoboridae. In: Fauna da Amazônia Brasileira. Belém, 9: 1-2.

Paradise, C.J. (2004), Relationship of water and leaf litter variabiliy to insects inhabiting treeholes. J. N. Am. Benthol. Soc., 23(4): 793-805.

Pereira, D.L.V.; Neiss, U.G. and Ferreira, R.L.M. (2007), Distribuição de Paravelia recens (Drake and Harris, 1935) (Hemiptera, Heteroptera, Veliidae) em Guzmania brasiliensis Ule, 1907 (Bromeliaceae) na Reserva Florestal Adolpho Ducke, Amazonas, Brasil. Acta Amazon., 37(1), 147-150.

Reiss, F. (1977), Qualitative and quantitative investigations on the macrobenthic fauna of Central Amazon lakes. Amazoniana, 6: 203-235.

Ribeiro, J.E.L.S.; Hopkins, M.J.G.; Vicentini, A.; Sothers, C. A.; Costa, M.A.S.; Brito, J.M.; Souza, M.A.D.; Martins, L.H.P.; Lohmann, L.G.; Assunçao, P.A.C.L.; Pereira, E.C.; Silva, C.F.; Mesquita, M.R. and Procopio, L.C. (1999), Flora da Reserva Ducke. Guia de identificação das plantas vasculares de uma floresta de terra-firme na Amazônia Central. Manaus, INPA-DFID, (19.ed). 816p.

Richardson, B.A. 1999. The bromeliad microcosm and the assessment of diversity in a neotropical forest. Biotropica, 31, 321-336.

Richardson, B.A.; Hull, G.A. (2000), Insect colonization sequences in bracts of Heliconia caribaea in Puerto Rico. Ecol Entomol, 25, 460-466.

Salamandra, N.P. (1980), Estudio bioecológico en Guzmania sp. (Bromeliaceae) y Heliconia bihai (Musaceae) em um Bosque Pluvial del Choco. Actual. Biol., 9(32), 31-50.

Sanchez, E.; Liria, J. (2009), Relative abundance and temporal variation of macroinvertebrates in a Venezuelan cloud forest habitat. Int. J. Trop. Insect Sci., 29(1), 3-10. 
Sota, T. (1998), Microhabitat size distribution affects local difference in community structure: metazoan community treeholes. Res. Popul. Ecol., 40: 249-255.

Thienemann, A. (1934), Der tierwelt der tropischen Planzengewässer. Arch. Hydrobiol., 13, 1-91.

Torreias, S.R.S. (2008), Macroinvertebrados associados a Vriesea splitgerberi (Mez.) L.B. Sm. and Pitten. (1953) (Bromeliaceae) em uma floresta de campinarana na Reserva Florestal Adolpho Ducke, Amazônia Central, Dissertação de Mestrado, Instituto Nacional de Pesquisas da Amazônia, Universidade Federal do Amazonas, Manaus, 92p.

Torreias, S.R.; Ferreira-Keppler, R.L.; Godoy, B.S and Hamada, N. (2010), Mosquitoes (Diptera, Culicidae) inhabiting foliar tanks of Guzmania brasiliensis Ule (Bromeliaceae) in central Amazonia, Brazil. Rev. Bras. Entomol., 54(4): 618-623.
Triplehorn, C.A.; Johnson, N.F. (2005), Borror and DeLong's Introduction to the Study of Insects. (7 ed.). Thomson Brooks/cole. 864pp.

Wallace, J.B.; Merritt, R.W. (1980), Filter-feeding ecology of aquatic insects. Ann. Rev. Entomol., 25, 103-132.

Varga, L. (1928), Ein interessanter biotop ther biocönose von wasserorganismen. Biol. Zbl., 48, 143162.

Zar, J.H. (1996), Biostatistical Analysis. Third. Prentice Hall, Upper Soddle River, New Jersey, x+662pp.

Received: June 09, 2010; Revised: January 20, 2011; Accepted: September 12, 2011. 